\title{
Anti-inflammatory and anti-rheumatic activities in vitro of alkaloids separated from Aconitum soongoricum Stapf
}

\author{
LIJUAN ZHANG $^{1}$, MUKADAISI SIYITI $^{1}$, JIANG ZHANG $^{1}$, MEIQI YAO $^{1}$ and FEICUI ZHAO ${ }^{1,2}$ \\ ${ }^{1}$ Department of Pharmacy, Xinjiang Medical University, Urumqi, Xinjiang 830011; ${ }^{2}$ Department of Pharmacy, \\ The Affiliated Chinese Medicine Hospital of Xinjiang Medical University, Urumqi, Xinjiang 830000, P.R. China
}

Received November 5, 2018; Accepted February 2, 2021

DOI: $10.3892 /$ etm.2021.9924

\begin{abstract}
The aim of the present study was to investigate the cell proliferation-inhibiting and anti-rheumatic activities of chemical components from Aconitum soongoricum Stapf. Chemical constituents of Aconitum soongoricum Stapf. were separated and purified by silica gel and Sephadex LH-20 chromatography. Structure was identified by spectroscopic technique, and physical/chemical properties were analyzed. The following four compounds were identified: i) Aconitine, ii) songorine, iii) 16,17 -dihydro- $12 \beta, 16 \beta$-epoxynapelline, and iv) 12-epi-napelline. Cell Counting kit- 8 assay was performed to assess cell proliferation. ELISA was conducted to determine the cytokine contents, and reverse transcription-quantitative polymerase chain reaction and Western blot analysis were performed to detect the mRNA and protein expression levels. Compared with the lipopolysaccharide (LPS) group, the contents of IL- 6 , IL- $1 \beta$, TNF- $\alpha$ and PGE- 2 in the culture supernatant were significantly declined in the leflunomide + LPS and intervention+LPS groups, as well as the mRNA expression levels of HIF-1 $\alpha$, VEGFA and TLR4. Treatments with songorine, benzoylaconine and aconitine (at different concentrations) significantly inhibited the proliferation of HFLS-RA cells. Compared with the LPS group, the contents of PGE-2, IL-6, IL-1 $\beta$ and TNF- $\alpha$ in the culture supernatant were significantly decreased in the intervention groups, and the mRNA expression levels of TLR4, HIF-1 $\alpha$ and VEGFA in the cells in the intervention groups. Songorine, benzoylaconine and aconitine from Aconitum soongoricum Stapf. have anti-rheumatic activities in vitro, which may inhibit the proliferation of HFLS-RA cells, and the underlying mechanisms may be associated with inhibiting the inflammatory cytokine production and
\end{abstract}

Correspondence to: Professor Feicui Zhao, Department of Pharmacy, The Affiliated Chinese Medicine Hospital of Xinjiang Medical University, 116 Huanghe Road, Shayibake, Urumqi, Xinjiang 830000, P.R. China

E-mail: 1017987429@qq.com

Key words: Aconitum soongoricum Stapf., alkaloids, chemical composition, anti-inflammation, anti-rheumatism downregulating the expression levels of HIF-1 $\alpha$, VEGF and TLR4.

\section{Introduction}

Aconitum soongoricum Stapf. is a type of perennial herb belonging to Ranunculaceae Aconitum, which is mainly distributed in Northern Xinjiang, China. Aconitum soongoricum Stapf. is abundantly produced in the Xinyuan, Nileke County, Altay in Yili, Xinjiang, in mountains and grassland slopes at an altitude of 1,800-2,600 meters (1-3). Its toxic root is used for medicinal purposes, including expelling wind and cold, relieving pain and swelling, and clearing meridians and collaterals (4). Aconitum soongoricum Stapf. has unique advantages in the treatment of rheumatic diseases, which is worthy of investigation $(5,6)$.

Aconitum soongoricum Stapf. has been shown to be related to the standard Radix Aconiti in molecular and chemical features, and the total alkaloid content is as high as $0.8 \%$. Aconitum soongoricum Stapf. has been used as a folk medicine by Kazakh herders, and no reports of associated adverse reactions have been reported. Pharmacological studies have demonstrated that Aconitum or its related alkaloids have analgesic, anti-inflammatory, antitumor, anti-arrhythmia and cardiotonic effects. Furthermore, the alkaloids in radix aconite, aconitine, mesaconitine and hypaconitine all have strong anti-inflammatory activities $(7,8)$. In the present study, the chemical constituents of Aconitum soongoricum Stapf. were investigated, and the total alkaloid contents were analyzed. A total of 4 alkaloids were obtained through the silica gel column chromatography and low-pressure column chromatography, which were subjected to EI-MS, IR, ${ }^{1} \mathrm{H}-\mathrm{NMR}$, and ${ }^{13} \mathrm{C}-\mathrm{NMR}$ spectral analyses, and identified as i) Aconitine, ii) songorine (Aconitum soongoricum Stapf.), iii) 16, 17-dihydro-12 $\beta$, $16 \beta$-epoxynapelline, and iv) 12-epi-napelline and 12-epidehydronapeline, respectively. Some of these alkaloids have been demonstrated to have anti-rheumatic effects (9). Therefore, further in-depth investigation is required to identify the unknown components in the Aconitum soongoricum Stapf.

Our previous study demonstrated that the raw and processed products of Aconitum soongoricum Stapf. may decline the serum levels of IL-1 $\beta$, IL- 2 and TNF- $\alpha$ in CIA and AA rats. The associated mechanisms underlying the anti-inflammatory effects require further in-depth studies (10). 


\section{Materials and methods}

Sample sources. Chinese herb samples were harvested from Nileke County, Yili, Xinjiang, in August 2012, which were identified as the dry roots of Aconitum soongoricum Stapf. by Yonghe Li (the chief Traditional Chinese Medicine pharmacist in the Fourth Clinical Medical College of Xinjiang Medical University).

Extraction and separation of alkaloids. The extraction and separation of alkaloids were performed as previously described $(11,12)$. In brief, $10 \mathrm{~kg}$ dry roots of Aconitum soongoricum Stapf. were crushed (through a 1x1 inch 20-mesh sieve) and extracted using 95\% ethanol (cat. no. 130105; Xi'an Chemical Reagent Factory) at $25^{\circ} \mathrm{C}$ and this was repeated 3 times (27 1 ethanol each time). The percolation extraction method was used (13). The dichloromethane extract was concentrated by a rotary evaporator at $40^{\circ} \mathrm{C}$ to remove the dichloromethane solvent, and the saturated n-butanol extract was concentrated by a rotary evaporator at $50^{\circ} \mathrm{C}$ to remove the n-butanol solvent. The extract was concentrated by thin-film evaporation, and then dissolved with $5.512 \% \mathrm{HCl}$ and extracted using petroleum ether (a total of 8 l; cat. no. 20131105; Tianjin Hongyan Reagent Factory). The remaining aqueous solution was adjusted to $\mathrm{pH}=4$ with ammonia solution, which was then subjected to the extraction with dichloromethane three times (6 1 each time; cat. no. 20131128; Tianjin Chemical Reagent Co., Ltd.). The dichloromethane extract was gathered, and the portion with $\mathrm{pH}=4$ was obtained. The remaining aqueous solution was adjusted to $\mathrm{pH}=8$ with ammonia solution, which was subjected to the extraction with dichloromethane three times (8 1 each time), and the dichloromethane phase was obtained $(\mathrm{pH}=8)$. The aqueous layer was adjusted to $\mathrm{pH}=11$ with $10 \% \mathrm{NaOH}$ and extracted using dichloromethane three times (6 1 each time) to obtain the portion with $\mathrm{pH}=11$. The aqueous layer was then extracted with saturated n-butanol (2 1), to obtain the n-butanol portion. The portions obtained were separated by the repeated silica gel, Sephadex LH-20 gel column (Amersham Pharmacia Biotech AB) and recrystallization. The fractions were concentrated, and the solvent was removed, prior to the column purification.

\section{Elution and identification of compounds 1-5}

Compound 1 . The $\mathrm{pH}=4$ portion was eluted with petroleum ether-ethyl acetate-diethylamine (cat. no. 20131213; Tianjin Hongyan Reagent Factory; 8:2:0.5, V/V/V; flow rate, $20 \mathrm{ml} / \mathrm{min}$; 11 eluate was collected each time), and the eluates from the 18th to 23th washing rounds were collected, gathered, crystallized and filtered, to obtain the Compound 1 (1.5449 g; solid colorless crystal), which was identified as a single compound by the thin layer chromatography (TLC; with the Rf value of 0.2 ), as previously described (14). The potassium bismuth iodide was used as the chromogenic agent for the TLC method.

Compound 2. The portion of $\mathrm{pH}=8$ was eluted with petroleum ether-ethyl acetate-diethylamine (10:1:0.5; flow rate, $20 \mathrm{ml} / \mathrm{min}$; 11 elute was collected each time), and the elutes from the 6 th to 11th rounds were collected, crystallized and filtered, to obtain Compound 2 (1.3345 g), which was determined to be a single compound according to the TLC (with an Rf value of 0.37 ).

Compound 3. The $\mathrm{pH}=8$ portion was eluted with petroleum ether-ethyl acetate-diethylamine (10:1:0.5; flow rate, $20 \mathrm{ml} / \mathrm{min}$; 11 elute was collected each time), and the elutes from the 1st to 3 rd rounds were collected, which were then subjected to the Sephadex LH-20 gel column, followed by eluting with chloroform-petroleum ether-methanol (5:5:1; at a flow rate of $5 \mathrm{ml} / \mathrm{min}$ ). A total of $15 \mathrm{ml}$ elute was collected each time, and the elute from the 7th eluting round was collected, crystallized, filtered and re-crystallized with acetone, to obtain Compound 3 (100 mg), identified as a single compound based on the TLC (with an Rf value of 0.52 ).

Compound 4 . The $\mathrm{pH}=8$ portion was eluted with petroleum ether-ethyl acetate-diethylamine (7:3:0.5; flow rate, $20 \mathrm{ml} / \mathrm{min}$; 1 lelute was collected each time), and the elutes from the 4 th to 9th rounds were collected, crystallized and filtered, to obtain Compound 4 (1.2910 g), identified as a single compound by TLC (with an Rf value of 0.6).

Compound 5. The $\mathrm{pH}=4$ portion was eluted with petroleum ether-ethyl acetate-diethylamine (10:1:0.5; flow rate, $20 \mathrm{ml} / \mathrm{min}$; 11 elute was collected each time), and the elutes from the 3rd to 7 th rounds were collected, subjected to the silica gel $\mathrm{H}$ column chromatography, followed by the petroleum ether-ethyl acetate-diethylamine (20:1:0.5) elution and pressurization. A total of $50 \mathrm{ml}$ elute was collected each time, and the elute from the 5th round was collected, concentrated, crystallized and filtered, to obtain Compound 5 (103 mg), identified as a single compound by TLC (with an Rf value of 0.82 ).

Structural identification. The obtained solid substance was subjected to the alkaloid physicochemical identification reaction and melting point ( $\mathrm{mp}$ ) measurement, and the molecular formula of the compound was obtained by ESI-MS as described previously (15). The reports on the diterpene alkaloids were retrieved from the literature, and the structural identification and analysis of the compounds were performed using ${ }^{1} \mathrm{H}-\mathrm{NMR}$ and ${ }^{13} \mathrm{C}-\mathrm{NMR}$ spectroscopy as described previously (16) (INOVA-600 and 400 model superconducting nuclear magnetic resonance instrument; Varian Medical Systems).

For the chromatographic conditions and system suitability test, the XBridgeTM-C18 column $(250 \times 4.6 \mathrm{~mm}, 5 \mu \mathrm{m}$; Waters Corporation) was used, with an octadecylsilane bonded silica filler. The methanol-water-chloroform-triethylamine (volume ratio of 67:33:2:0.1) was used as the mobile phase, and isocratic elution was performed. The conditions were set as follows: The flow rate, $0.8 \mathrm{ml} / \mathrm{min}$; detection wavelength, $235 \mathrm{~nm}$; column temperature, $40^{\circ} \mathrm{C}$; injection volume, $10 \mu \mathrm{l}$.

Study cells and grouping. Rheumatoid arthritis HFLS-RA fibroblast-like synoviocytes (suitable for the experiments) (17-19) were derived from Bena Culture Collection (BNCC340356). These cells were cultured using high-glucose Dulbecco's modified Eagle's medium (12800-017; Gibco; Thermo Fisher Scientific, Inc.), containing 10\% FBS (FND500; Shanghai ExCell Biology, Inc.), supplemented 
with $1 \%$ penicillin-streptomycin double antibodies $(10,000 \mathrm{U}$; SC30010; Gibco; Thermo Fisher Scientific, Inc.) in a $37^{\circ} \mathrm{C}, 5 \%$ $\mathrm{CO}_{2}$ incubator, with saturated humidity. The HFLS-RA cells at a confluence of $90 \%$ were subjected to the following treatments: i) The blank group, including the normal cultured cells; ii) the lipopolysaccharide (LPS) intervention group, in which the cells were treated with medium containing $100 \mathrm{ng} / \mathrm{ml}$ LPS for $26 \mathrm{~h}$; iii) the Leflunomide + LPS intervention group, in which the cells were treated with medium containing $100 \mathrm{ng} / \mathrm{ml}$ LPS for $2 \mathrm{~h}$, followed by treatment together with $150 \mu \mathrm{g} / \mathrm{ml}$ leflunomide for another $24 \mathrm{~h}$; iv) the Junggar aconitine + LPS intervention group, in which the cells were treated with medium containing $100 \mathrm{ng} / \mathrm{ml}$ LPS for $2 \mathrm{~h}$, followed by treatment together with $350 \mu \mathrm{g} / \mathrm{ml}$ Junggar aconitine for a further $24 \mathrm{~h}$; v) the benzoylaconine + LPS intervention group, in which the cells were treated with medium containing $100 \mathrm{ng} / \mathrm{ml}$ LPS for $2 \mathrm{~h}$, followed by treatment together with $1,000 \mu \mathrm{g} / \mathrm{ml}$ benzoylaconine for a further $24 \mathrm{~h}$; and vi) the aconine + LPS intervention group, in which the cells were treated with medium containing $100 \mathrm{ng} / \mathrm{ml}$ LPS for $2 \mathrm{~h}$, followed by treatment together with $500 \mu \mathrm{g} / \mathrm{ml}$ aconine for a further $24 \mathrm{~h}$. All treatments were performed at $37^{\circ} \mathrm{C}$.

Compound preparation. To prepare the songorine stock solution (prepared by Traditional Chinese Medicine Pharmacy Laboratory and Traditional Chinese Medicine Processing Research Laboratory, Xinjiang Medical University, Urumqi, China ), a total of $100 \mathrm{mg}$ substrate was weighed and dissolved in $500 \mu \mathrm{l}$ DMSO (D2650; Sigma-Aldrich; Merck KGaA), to obtain a final concentration of $200 \mathrm{mg} / \mathrm{ml}$. To prepare the benzoylaconine stock solution (A0631; Chengdu Must Bio-Technology Co., Ltd.), a total of $20 \mathrm{mg}$ benzoylaconine was weighed and dissolved in $100 \mu \mathrm{l}$ DMSO, to obtain a final concentration of $200 \mathrm{mg} / \mathrm{ml}$. To prepare the aconitine stock solution (MUST-14012802; Chengdu Must Bio-Technology Co., Ltd.), a total of $100 \mathrm{mg}$ drug was weighed and dissolved in $100 \mu \mathrm{l}$ DMSO to obtain a final concentration of $200 \mathrm{mg} / \mathrm{ml}$.

Cell Counting kit-8 (CCK-8) assay. Cells were seeded onto the $96-w e l l$ plate, at a density of $5 \times 10^{4}$ cells $/ \mathrm{ml}$. After 8 days, the culture medium was replaced with $10 \%$ CCK- 8 solution (Beyotime Institute of Biotechnology), and the cells were incubated at $37^{\circ} \mathrm{C}$ for $1 \mathrm{~h}$. Next, the optical density (OD) was read on the xMarkTM microplate reader (Bio-Rad Laboratories, Inc.) at an absorbance of $450 \mathrm{~nm}$, and the growth curve was plotted accordingly. The inhibition rate was calculated using the following formulation: Inhibition rate $=\left(\mathrm{OD}_{\text {blank control }}-\mathrm{OD}_{\text {sample }}\right) /\left(\mathrm{OD}_{\text {blank control }}-\mathrm{OD}_{\text {reagent control }}\right)$ $\mathrm{x} 100 \%$. The $\mathrm{IC}_{50}$ value was calculated by the probit analysis using SPSS 19.0 software (IBM Corp.).

HFLS-RA cell viability. Cells were seeded onto a 96-well plate, at a density of $5 \times 10^{4}$ cells $/ \mathrm{ml}$, and cultured in a $37^{\circ} \mathrm{C}, 5 \% \mathrm{CO}_{2}$ incubator for $24 \mathrm{~h}$. Following adhering, the cells were incubated with $100 \mu \mathrm{l}$ songorine at indicated concentrations $(0,100,300$, 500, 700 and $900 \mu \mathrm{g} / \mathrm{ml}), 100 \mu \mathrm{l}$ benzoylaconine at indicated concentrations $(0,500,1,000,1,500,2,000$ and $3,000 \mu \mathrm{g} / \mathrm{ml})$, or $100 \mu \mathrm{l}$ aconitine at indicated concentrations $(0,100,500$, $1,000,1,500$ and $2,000 \mu \mathrm{g} / \mathrm{ml})$. After 24,48 and $72 \mathrm{~h}$, the culture medium was discarded, and the cells were treated with
$100 \mu \mathrm{l} 10 \% \mathrm{CCK}-8$ solution for at $37^{\circ} \mathrm{C}$ for $1.5 \mathrm{~h}$. Next, the OD was read at $450 \mathrm{~nm}$ using a microplate reader. Cell images were captured using a fluorescence inverted microscope (magnification, x200; Eclipse TS100-F; Nikon).

ELISA. The contents of IL-6 (EH004-48; Shanghai ExCell Biology, Inc.), IL-1 $\beta$ (EH001-48; Shanghai ExCell Biology, Inc.), TNF- $\alpha$ (EH009-481; Shanghai ExCell Biology, Inc.) and PG-E2 (CSB-E07965h; Wuhan Huamei Bioengineering Co., Ltd.) in the culture supernatant were measured using ELISA kits. Cells were seeded onto the 96 -well plate at a density of $5 \times 10^{4}$ cells $/ \mathrm{ml}$, and cultured in a $37^{\circ} \mathrm{C}, 5 \% \mathrm{CO}_{2}$ incubator for $24 \mathrm{~h}$. Drug intervention was performed following cell adhering and, at $2 \mathrm{~h}$ before intervention, the cells were treated with $100 \mathrm{ng} / \mathrm{ml}$ lipopolysaccharides (LPS; L6529-1MG; Sigma-Aldrich; Merck KGaA) at $37^{\circ} \mathrm{C}$ for $24 \mathrm{~h}$. The LPS treatment was to simulate an in vitro inflammatory model and the cells would produce an inflammatory reaction following LPS treatment (20). Next, the cells were treated with $150 \mu \mathrm{g} / \mathrm{ml}$ leflunomide, $350 \mu \mathrm{g} / \mathrm{ml}$ songorine, $1,000 \mu \mathrm{g} / \mathrm{ml}$ benzoylaconine and $500 \mu \mathrm{g} / \mathrm{ml}$ aconitine at $37^{\circ} \mathrm{C}$ for $24 \mathrm{~h}$. ELISA was performed with commercially available kits (IL-6 kit,EH004-48, Shanghai ExCell Biology, Inc.; IL-1 $\beta$ kit, EH001-48, Shanghai ExCell Biology, Inc.; TNF- $\alpha$ kit, EH009-48, Shanghai ExCell Biology, Inc.; and PG-E2 kit, CSB-E07965h, CUSABIO), according to the manufacturer's protocols.

Reverse transcription-quantitative polymerase chain reaction $(R T-q P C R)$. Total RNA was extracted from the cells using TRIzol reagent (Invitrogen; Thermo Fisher Scientific, Inc.). The cDNA was obtained using the TransScript One-Step gDNA Removal and cDNA Synthesis SuperMix (AT311; TransGen Biotech Co., Ltd.) for $25^{\circ} \mathrm{C}$ for $10 \mathrm{~min}, 42^{\circ} \mathrm{C}$ for $30 \mathrm{~min}$ and $85^{\circ} \mathrm{C}$ for $5 \mathrm{sec}$. RT-qPCR was performed using the QuantiNava SYBR-Green kit (208054; Kaijie). Primer sequences were as follows: HIF-1 $\alpha$ forward, 5'-CACCAC AGGACAGTACAGGAT-3' and reverse, 5'-CGTGCTGAA TAATACCACTCACA-3'; VEGFA forward, 5'-CAGAAG GAGGAGGGCAGAATC-3' and reverse, 5'-GGTCTCGAT TGGATGGCAGT-3'; TLR4 forward, 5'-AGACCTGTCCCT GAACCCTAT-3' and reverse, 5'-CGATGGACTTCTAAA CCAGCCA-3'; and $\beta$-actin forward, 5'-ACAGAGCCTCGC CTTTGCC-3' and reverse, 5'-GAGGATGCCTCTCTTGCT CTG-3'. The PCR system consisted of $5 \mu \mathrm{l}$ SYBR Select mix,

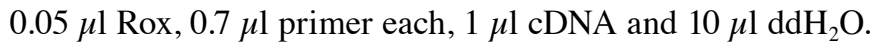
The reaction conditions were as follows: $94^{\circ} \mathrm{C}$ for $30 \mathrm{sec} ; 94^{\circ} \mathrm{C}$ for $5 \mathrm{sec}$, for a total of 40 cycles; followed by $60^{\circ} \mathrm{C}$ for $34 \mathrm{sec}$. Target gene expression levels were calculated using the $2^{-\Delta \Delta \mathrm{CT}}$ method (21).

Western blot analysis. Cells were collected and lysed using RIPA lysis buffer (Boster Biological Technology). Protein concentrations were determined using the BSA method. A total of $30 \mathrm{mg}$ protein per lane was separated by $10 \%$ SDS-PAGE, which was then electronically transferred onto polyvinylidene difluoride membranes. Following blocking with $5 \%$ skimmed milk at room temperature for $1 \mathrm{~h}$, the membrane was incubated with primary antibodies against HIF-1 $\alpha$ (1:1,000 dilution; cat. no. ab113642; Abcam), VEGFA (1:1,000 dilution; cat. no. ab1316; Abcam), TLR4 (1:1,000 
Table I. The ${ }^{1} \mathrm{H}-\mathrm{NMR}$ data of compounds 1-5.

\begin{tabular}{|c|c|c|}
\hline Compound & & ${ }^{1} \mathrm{H}-\mathrm{NMR}$ \\
\hline 1 & Aconitine & $\begin{array}{l}(400 \mathrm{MHz}, \mathrm{CDCl} 3) \delta \mathrm{ppm}: 1.10(\mathrm{t}, \mathrm{J}=7.0 \mathrm{~Hz}, 3 \mathrm{H}, \mathrm{NCH} 2 \mathrm{CH} 3), 1.39(\mathrm{~s}, 3 \mathrm{H}, \mathrm{COCH} 3) \\
3.11,3.27,3.34,3.75(\mathrm{~s} \text {, each } 3 \mathrm{H}, \mathrm{OCH} 3), 4.04(\mathrm{~d}, \mathrm{~J}=6.5 \mathrm{~Hz}, 1 \mathrm{H}, 6-\beta \mathrm{H}), 4.48(\mathrm{~s}, 1 \mathrm{H}), \\
4.88(\mathrm{~d}, \mathrm{~J}=4.8 \mathrm{~Hz}, 1 \mathrm{H}, 14-\alpha \mathrm{H}), 8.03(\mathrm{~d}, \mathrm{~J}=7.6 \mathrm{~Hz}, 2 \mathrm{H}, \mathrm{Ar}-\mathrm{H}), 7.66-7.39(\mathrm{~m}, 3 \mathrm{H}, \mathrm{Ar}-\mathrm{H})\end{array}$ \\
\hline 2 & Songorine & $\begin{array}{l}(400 \mathrm{MHz}, \mathrm{CDCl} 3) \delta p p m: 0.77(\mathrm{~s}, 4 \mathrm{H}, 18-\mathrm{CH} 3), 1.07(\mathrm{t}, \mathrm{J}=6.8 \mathrm{~Hz}, 3 \mathrm{H}, \mathrm{NCH} 2 \mathrm{CH} 3) \\
3.10(\mathrm{~d}, \mathrm{~J}=2.4 \mathrm{~Hz}, 1 \mathrm{H}), 3.34(\mathrm{dd}, \mathrm{J}=17.1,11.7 \mathrm{~Hz}, 2 \mathrm{H}), 3.45(\mathrm{~s}, 1 \mathrm{H}, 15-\mathrm{H}), 3.85(\mathrm{~s}, 1 \mathrm{H}, \\
1-\beta \mathrm{H}), 4.36(\mathrm{~d}, \mathrm{~J}=8.1 \mathrm{~Hz}, 1 \mathrm{H}, 15-\alpha \mathrm{H}), 5.20,5.30(\mathrm{~s}, 2 \mathrm{H}, 17-\mathrm{CH} 2)\end{array}$ \\
\hline 3 & $\begin{array}{l}\text { 16, 17-dihydro- } 12 \beta \\
16 \beta \text {-epoxynapelline }\end{array}$ & $\begin{array}{l}(400 \mathrm{MHz}, \mathrm{CDCl} 3) \delta \text { ppm: } 0.74(3 \mathrm{H}, \mathrm{s}, 18-\mathrm{CH} 3), 1.04(3 \mathrm{H}, \mathrm{t}, \mathrm{J}=8 \mathrm{~Hz}, 22-\mathrm{H}), 1.38(3 \mathrm{H}, \\
\mathrm{s}, 17-\mathrm{CH} 3), 1.78(1 \mathrm{H}, \mathrm{d}, \mathrm{J}=6 \mathrm{~Hz}, 14 \alpha-\mathrm{H}), 2.71(1 \mathrm{H}, \mathrm{dd}, \mathrm{J}=4,8 \mathrm{~Hz}, 13-\mathrm{H}), 3.42(1 \mathrm{H}, \mathrm{brs}, \\
20-\mathrm{H}), 3.47(1 \mathrm{H}, \mathrm{s}, 15-\mathrm{H}), 3.88(1 \mathrm{H}, \mathrm{dd}, \mathrm{J}=16.3,9.4 \mathrm{~Hz}, 1-\mathrm{H}), 4.83(1 \mathrm{H}, \mathrm{dd}, \mathrm{J}=7.7, \\
3.9 \mathrm{~Hz}, 12-\mathrm{H})\end{array}$ \\
\hline 4 & 12-epi-napellin & $\begin{array}{l}(400 \mathrm{MHz}, \mathrm{CDCl} 3) \delta \text { ppm: } 0.77(3 \mathrm{H}, \mathrm{s}, 18-\mathrm{CH} 3), 1.09(3 \mathrm{H}, \mathrm{t}, \mathrm{J}=4 \mathrm{~Hz}, \mathrm{NCH} 2 \mathrm{CH} 3) \\
3.91(1 \mathrm{H}, \mathrm{br}, \mathrm{s}, 1-\beta \mathrm{H}), 4.20(1 \mathrm{H}, \mathrm{dd}, \mathrm{J}=15.9,7.2 \mathrm{~Hz}, 12-\alpha \mathrm{H}), 5.13,5.34(2 \mathrm{H}, \mathrm{s}, 17-\mathrm{CH} 2)\end{array}$ \\
\hline 5 & Deoxyaconitine & $\begin{array}{l}(500 \mathrm{MHz}, \mathrm{CDCl} 3) \delta p p m: 1.09(3 \mathrm{H}, \mathrm{t}, \mathrm{J}=7 \mathrm{~Hz}, \mathrm{NCH} 2 \mathrm{CH} 3), 1.39(3 \mathrm{H}, \mathrm{s}, \mathrm{COCH} 3), \\
3.18,3.29,3.31,3.76(\text { each } 3 \mathrm{H}, \mathrm{s}, 4 \mathrm{x}-\mathrm{OCH} 3), 4.39(1 \mathrm{H}, \mathrm{d}, \mathrm{J}=3 \mathrm{~Hz}, 15-\alpha \mathrm{OH}), 4.48(1 \mathrm{H}, \\
\mathrm{dd}, \mathrm{J}=3,5.5 \mathrm{~Hz}, 15-\beta \mathrm{H}), 4.89(1 \mathrm{H}, \mathrm{d}, \mathrm{J}=5 \mathrm{~Hz}, 14-\beta \mathrm{H}), 7.42-8.08(5 \mathrm{H}, \mathrm{m}, \mathrm{Ar}-\mathrm{H})\end{array}$ \\
\hline
\end{tabular}

A

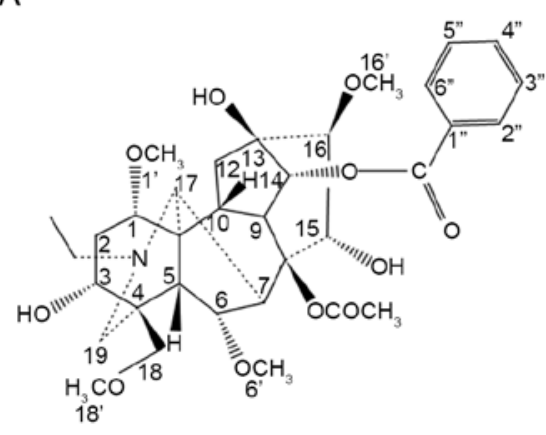

D

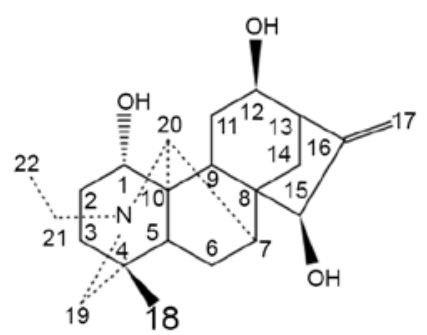

B

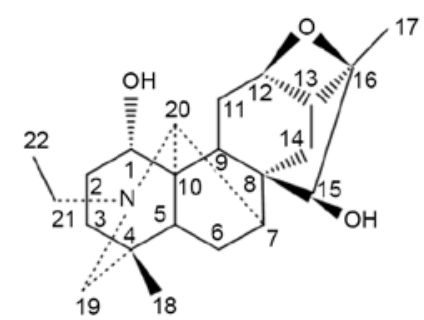

E

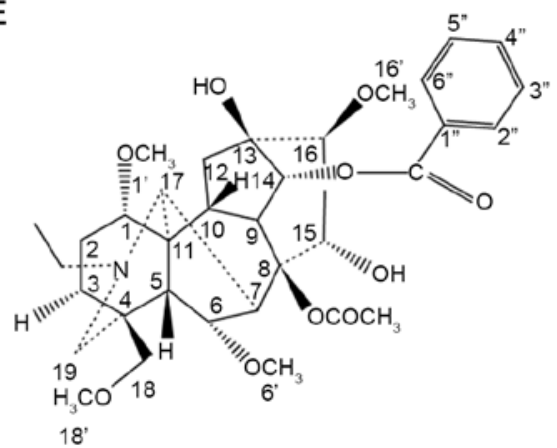

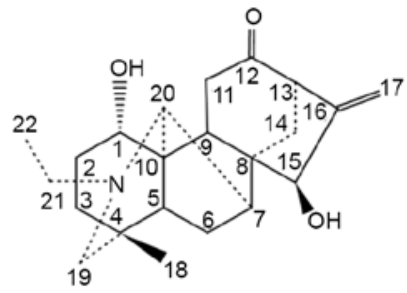

Figure 1. Chemical structures of alkaloids isolated and identified from Aconitum soongoricum Stapf. (A) Aconitine. (B) Songorine. (C) 16,17-dihydro-12ß,16 $\beta$-epoxynapelline. (D) 12-epi-napelline. (E) Deoxyaconitine.

dilution; cat. no. ab13867; Abcam) and $\beta$-actin (1:800 dilution; cat. no. D110024; Sangon Biotech) at $4^{\circ} \mathrm{C}$ overnight. Next, the membranes were incubated with the HRP-conjugated pierce goat anti-rabbit IgG (1:10,000 dilution; cat. no. 31460; Thermo Fisher Scientific, Inc.) or pierce goat anti-mouse IgG (1:10,000 dilution; cat. no. 31430; Thermo Fisher Scientific, Inc.) at room temperature for $1 \mathrm{~h}$. The protein bands were detected using the SuperSignal West Prico Chemiluminescent Substrate (34080; Thermo Fisher Scientific, Inc.), and the images were captured and analyzed using Chemi Analysis software.
Statistical analysis. Data are expressed as the mean \pm standard deviation. SPSS 19.0 software (IBM Corp.) was used for statistical analysis. Experiments were performed in triplicates. One-way analysis of variance, followed by Tukey's test, was performed for group comparisons. $\mathrm{P}<0.05$ was considered to indicate a statistically significant difference.

\section{Results}

Identification and characterization of obtained compounds. Compound 1 was a colorless solitary crystal. The ${ }^{1} \mathrm{H}-\mathrm{NMR}$ 
Table II. Comparison of ${ }^{13} \mathrm{C}$ NMR data between compound 1 and aconitine $(100 \mathrm{MHz})$.

\begin{tabular}{|c|c|c|}
\hline $\mathrm{C}$ & Aconitine (6) & Compound 1 \\
\hline 1 & 82.00 & 82.38 \\
\hline 2 & 33.10 & 33.63 \\
\hline 3 & 71.00 & 71.55 \\
\hline 4 & 43.10 & 43.14 \\
\hline 5 & 46.30 & 46.85 \\
\hline 6 & 83.20 & 83.38 \\
\hline 7 & 44.60 & 44.70 \\
\hline 8 & 91.70 & 92.06 \\
\hline 9 & 44.00 & 44.21 \\
\hline 10 & 40.70 & 40.90 \\
\hline 11 & 49.90 & 50.00 \\
\hline 12 & 35.60 & 35.83 \\
\hline 13 & 73.90 & 74.05 \\
\hline 14 & 78.70 & 78.92 \\
\hline 15 & 78.60 & 78.85 \\
\hline 16 & 89.80 & 89.97 \\
\hline 17 & 61.10 & 61.15 \\
\hline 18 & 76.50 & 76.69 \\
\hline 19 & 47.20 & 46.86 \\
\hline 20 & 48.10 & 48.93 \\
\hline 21 & 13.00 & 13.35 \\
\hline $1^{\prime}$ & 55.80 & 55.94 \\
\hline $6^{\prime}$ & 58.00 & 58.00 \\
\hline $16^{\prime}$ & 61.10 & 61.02 \\
\hline $18^{\prime}$ & 59.00 & 59.13 \\
\hline $\mathrm{COCH}_{3}$ & 172.30 & 172.43 \\
\hline $\mathrm{COCH}_{3}$ & 21.30 & 21.45 \\
\hline $\mathrm{ArCO}$ & 166.00 & 166.08 \\
\hline $1^{\prime \prime}$ & 129.60 & 129.78 \\
\hline $2^{\prime \prime}$ & 129.50 & 129.61 \\
\hline $3^{\prime \prime}$ & 128.60 & 128.65 \\
\hline $4^{\prime \prime}$ & 133.20 & 133.29 \\
\hline
\end{tabular}

(400 MHz, CDCl3) indicated 1 nitrogen ethyl group ( $\mathrm{\delta H}: 1.10$, $3 \mathrm{H}, \mathrm{t}, \mathrm{J}=7.0 \mathrm{~Hz}$ ); and 4 methoxy groups $(\delta \mathrm{H}: 3.11,3.27,3.34$, 3.75 , s, each $3 \mathrm{H}$; Table I). The chemical shift in the ${ }^{13} \mathrm{C}-\mathrm{NMR}$ spectroscopy was virtually the same as the features for aconitine according to a previous study (22) (Table II). Based on the ESI/MS, the molecular ion peak m/z was found at 646 $[\mathrm{M}+\mathrm{H}]^{+}$. According to the nitrogen rule, it was inferred that the compound contained an odd number of nitrogen atoms. The ${ }^{13} \mathrm{C}$-NMR showed 34 carbon signals. Accordingly, the molecular formula was inferred as $\mathrm{C}_{34} \mathrm{H}_{47} \mathrm{NO}_{11}$, with an unsaturation degree of 12 . NMR suggested that it may be a $\mathrm{C}_{19}$-aconitine-type diterpene alkaloid. The compound and aconitine reference substance developed the same color spots at the same positions in various TLC developments. The compound structure is presented in Fig. 1A.

Compound 2 was a colorless solitary crystal. Its ${ }^{1} \mathrm{H}-\mathrm{NMR}$ data are presented in Table I. The chemical shift in the ${ }^{13} \mathrm{C}-\mathrm{NMR}$ spectroscopy was virtually the same as the features
Table III. Comparison of ${ }^{13} \mathrm{C}$ NMR data between compound 2 and songorine $(100 \mathrm{MHz})$.

\begin{tabular}{lrc}
\hline $\mathrm{C}$ & Songorine $(7)$ & Compound 2 \\
\hline 1 & 70.40 & 70.37 \\
2 & 31.50 & 31.66 \\
3 & 31.90 & 32.24 \\
4 & 34.10 & 34.11 \\
5 & 49.10 & 49.19 \\
6 & 23.60 & 23.23 \\
7 & 43.70 & 43.51 \\
8 & 49.90 & 50.03 \\
9 & 35.10 & 35.21 \\
10 & 52.10 & 52.42 \\
11 & 37.20 & 37.33 \\
12 & 209.00 & 209.9 \\
13 & 53.60 & 53.79 \\
14 & 38.00 & 38.13 \\
15 & 77.30 & 77.22 \\
16 & 150.90 & 151.08 \\
17 & 111.60 & 111.42 \\
18 & 26.00 & 26.07 \\
19 & 57.20 & 57.41 \\
20 & 66.00 & 66.01 \\
$\mathrm{~N}-\mathrm{CH}_{2} \mathrm{CH}_{3}$ & 50.80 & 50.91 \\
$\mathrm{~N}-\mathrm{CH}_{2} \mathrm{CH}_{3}$ & 13.50 & 13.63 \\
\hline & &
\end{tabular}

for songorine in a previous study (23) (Table III). Based on the ESI/MS, the molecular ion peak $\mathrm{m} / \mathrm{z}$ was observed at 358 $[\mathrm{M}+\mathrm{H}]^{+}$. According to the nitrogen rule, it was inferred that the compound contained an odd number of nitrogen atoms. The ${ }^{13} \mathrm{C}-\mathrm{NMR}$ showed 22 carbon signals. Accordingly, the molecular formula was inferred as $\mathrm{C}_{22} \mathrm{H}_{31} \mathrm{NO}_{3}$, with an unsaturation degree of 8. NMR suggested that it may be a $\mathrm{C}_{20}$-napelline-type diterpene alkaloid. Therefore, the compound was identified as songorine. The compound structure is presented in Fig. 1B.

Compound 3 was a colorless amorphous powder. The ${ }^{1} \mathrm{H}-\mathrm{NMR}$ (400 MHz, CDCl3) indicated 1 nitrogen ethyl group ( $\delta \mathrm{H}: 1.04,3 \mathrm{H}, \mathrm{t}, \mathrm{J}=8 \mathrm{~Hz}$ ), $1 \mathrm{CH}$ group $(\delta \mathrm{H}: 3.42,1 \mathrm{H}, \mathrm{brs})$ and 2 $\mathrm{CH} 3$ groups ( $\mathrm{\delta H}: 0.74,1.38$, s, each $3 \mathrm{H}$; Table I). The chemical shift in the ${ }^{13} \mathrm{C}-\mathrm{NMR}$ spectroscopy was virtually the same as the features for 16, 17-dihydro-12 $\beta, 16 \beta$-epoxynapelline according to a previous study (24) (Table IV). Based on the ESI/MS, the molecular ion peak $\mathrm{m} / \mathrm{z}$ was observed at 360 $[\mathrm{M}+\mathrm{H}]^{+}$. According to the nitrogen rule, it was inferred that the compound contained an odd number of nitrogen atoms. The ${ }^{13} \mathrm{C}-\mathrm{NMR}$ showed 22 carbon signals. Accordingly, the molecular formula was inferred as $\mathrm{C}_{22} \mathrm{H}_{33} \mathrm{NO}$, with an unsaturation degree of 7. NMR suggested that it may be $\mathrm{C}_{20}$-napelline-type diterpene alkaloid. Therefore, the compound was identified as 16,17 -dihydro-12 $\beta, 16 \beta$-epoxynapelline. The compound structure is presented in Fig. 1C.

Compound 4 was a colorless amorphous powder. The ${ }^{1} \mathrm{H}-\mathrm{NMR}$ (400 MHz, CDCl3) indicated 1 nitrogen ethyl group ( $\delta \mathrm{H}: 1.09,3 \mathrm{H}, \mathrm{t}, \mathrm{J}=4 \mathrm{~Hz}), 1 \mathrm{CH}$ group $(\delta \mathrm{H}: 3.91,1 \mathrm{H}$, brs) and 
Table IV. Comparison of ${ }^{13} \mathrm{C}$ NMR data between compound 3 and 16,17-dihydro-12 $\beta, 16 \beta$-epoxynapelline (100 MHz).

\begin{tabular}{|c|c|c|}
\hline $\mathrm{C}$ & 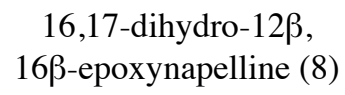 & Compound 3 \\
\hline 1 & 70.90 & 70.86 \\
\hline 2 & 32.10 & 31.97 \\
\hline 3 & 38.00 & 38.22 \\
\hline 4 & 33.80 & 33.88 \\
\hline 5 & 51.30 & 51.29 \\
\hline 6 & 22.50 & 22.52 \\
\hline 7 & 43.40 & 43.39 \\
\hline 8 & 49.20 & 49.22 \\
\hline 9 & 38.10 & 38.03 \\
\hline 10 & 51.40 & 51.53 \\
\hline 11 & 26.00 & 26.00 \\
\hline 12 & 77.40 & 77.51 \\
\hline 13 & 38.50 & 38.55 \\
\hline 14 & 28.70 & 28.76 \\
\hline 15 & 79.70 & 79.73 \\
\hline 16 & 89.20 & 89.33 \\
\hline 17 & 21.80 & 21.84 \\
\hline 18 & 25.90 & 26.00 \\
\hline 19 & 57.30 & 57.28 \\
\hline 20 & 66.40 & 66.54 \\
\hline 21 & 50.90 & 50.79 \\
\hline 22 & 13.60 & 13.61 \\
\hline
\end{tabular}

$1 \mathrm{CH} 3$ group ( $\delta \mathrm{H}: 0.77, \mathrm{~s}, 3 \mathrm{H}$; Table I). The chemical shift in the ${ }^{13} \mathrm{C}$-NMR spectroscopy was virtually the same as the features for 12-epi-napelline according to a previous study (25) (Table V). Based on the ESI/MS, the molecular ion peak $\mathrm{m} / \mathrm{z}$ was observed at $360[\mathrm{M}+\mathrm{H}]^{+}$. According to the nitrogen rule, it was inferred that the compound contained an odd number of nitrogen atoms. The ${ }^{13} \mathrm{C}-\mathrm{NMR}$ showed 22 carbon signals. Accordingly, the molecular formula was inferred as $\mathrm{C}_{22} \mathrm{H}_{33} \mathrm{NO}$, with an unsaturation degree of 7 . NMR suggested that it may be a $\mathrm{C}_{20}$-napelline-type diterpene alkaloid. Therefore, the compound was identified as 12-epi-napelline. The compound structure is presented in Fig. 1D.

Compound 5 was a colorless amorphous powder, with an $\mathrm{mp}$ of $169-170{ }^{\circ} \mathrm{C}, \mathrm{C}_{34} \mathrm{H}_{47} \mathrm{NO}_{10}$, ESI/MS $\left([\mathrm{M}+\mathrm{H}]^{+}, \mathrm{m} / \mathrm{z} 630\right)$, ${ }^{1} \mathrm{H}-\mathrm{NMR}\left(500 \mathrm{MHz}, \mathrm{CDCl}_{3}\right.$ ) $\delta$ ppm: 1.09 (3 $\mathrm{H}$ each, t $J=7 \mathrm{~Hz}$, $\left.\mathrm{NCH}_{2} \mathrm{CH}_{3}\right), 1.39$ (3 $\mathrm{H}$ each, s, $\mathrm{COCH}_{3}$ ), 3.18, 3.29, 3.31, 3.76 (3 $\mathrm{H}$ each, s, 4x-OCH$\left.{ }_{3}\right), 4.39$ (1 $\mathrm{H}$ each, d, $\left.J=3 \mathrm{~Hz}, 15-\alpha \mathrm{OH}\right), 4.48$ $(1 \mathrm{H}$ each, dd, $J=3,5.5 \mathrm{~Hz}, 15-\beta \mathrm{H}), 4.89(1 \mathrm{H}$ each, d, $J=5 \mathrm{~Hz}$, $14-\beta \mathrm{H}), 7.42-8.08$ (5 H each, m, Ar-H; Table I).

The aforementioned data, as well as the results from the ${ }^{13} \mathrm{C}-\mathrm{NMR}$ spectroscopy, were virtually the same as the features for deoxyaconitine, according to a previous study (24) (Table VI). Based on the ESI/MS, the molecular ion peak $\mathrm{m} / \mathrm{z}$ was observed at $630[\mathrm{M}+\mathrm{H}]^{+}$. According to the nitrogen rule, it was inferred that the compound contained an odd number of nitrogen atoms. The ${ }^{13} \mathrm{C}-\mathrm{NMR}$ showed 34 carbon signals. Accordingly, the molecular formula was inferred as $\mathrm{C}_{34} \mathrm{H}_{47} \mathrm{NO}_{10}$,
Table V. Comparison of ${ }^{13} \mathrm{C}$ NMR data between compound 4 and ${ }^{12}$-epi-napelline (100 MHz).

\begin{tabular}{rrr}
\hline C & 12-epi-napelline (6) & Compound 4 \\
\hline 1 & 67.20 & 67.10 \\
2 & 29.70 & 29.57 \\
3 & 31.70 & 31.60 \\
4 & 33.80 & 33.77 \\
5 & 48.80 & 48.58 \\
6 & 23.60 & 23.58 \\
7 & 44.00 & 43.84 \\
8 & 51.10 & 51.04 \\
9 & 37.20 & 37.02 \\
10 & 52.60 & 52.54 \\
11 & 32.70 & 32.64 \\
12 & 70.00 & 69.89 \\
13 & 44.00 & 43.88 \\
14 & 36.30 & 36.05 \\
15 & 77.00 & 77.23 \\
16 & 155.00 & 155.00 \\
17 & 111.40 & 111.55 \\
18 & 26.30 & 26.40 \\
19 & 58.30 & 58.29 \\
20 & 66.20 & 66.33 \\
21 & 50.90 & 50.93 \\
22 & 13.30 & 13.47 \\
\hline
\end{tabular}

with an unsaturation degree of 12 . NMR suggested that it may be a $\mathrm{C}_{20}$-aconitine-type diterpene alkaloid. Therefore, the compound was identified as deoxyaconitine. The compound structure is presented in Fig. 1E.

Effects of compound interventions on the growth of HFLS-RA cells. The proliferation of HFLA-RA cells was assessed using the CCK-8 assay, and a growth curve was obtained. At $24 \mathrm{~h}$ after seeding, the cells were in the latency phase, and at $48 \mathrm{~h}$ they were in the logarithmic growth phase. Starting from the 4th day, the growth platform began and it lasted until day 7 (Fig. 2). The effects of drug interventions on the growth of HFLS-RA cells were then assessed (Fig. 3A-D). The results of the present study demonstrated that, for the effects of songorine on the cell proliferation, the $\mathrm{IC}_{50}$ values for the intervention for 24,48 and $72 \mathrm{~h}$ were $491.4,436.7$ and $385.6 \mu \mathrm{g} / \mathrm{ml}$, respectively (Fig. 3E). Furthermore, the $\mathrm{IC}_{50}$ values for the benzoylaconine intervention for 24,48 and $72 \mathrm{~h}$ were 1,632.0, $1,552.6$ and $1,332.5 \mu \mathrm{g} / \mathrm{ml}$, respectively (Fig. 3E). Furthermore, the $\mathrm{IC}_{50}$ values for the aconitine intervention for 24,48 and $72 \mathrm{~h}$ were $775.1,679.9$ and $609.9 \mu \mathrm{g} / \mathrm{ml}$, respectively (Fig. 3E). These results suggested that songorine, benzoylaconine and aconitine at different concentrations may inhibit the proliferation of HFLS-RA cells, to different extents.

Effects of compound interventions on cytokine contents in culture supernatant. The effects of drug interventions on the cytokine contents in culture supernatant were subsequently 
Table VI. Comparison of ${ }^{13} \mathrm{C}$ NMR data between compound 5 and deoxyaconitine (100 MHz).

\begin{tabular}{|c|c|c|}
\hline $\mathrm{C}$ & Deoxyaconitine (9) & Compound 5 \\
\hline 1 & 85.10 & 85.29 \\
\hline 2 & 26.20 & 26.41 \\
\hline 3 & 35.10 & 35.30 \\
\hline 4 & 39.00 & 39.08 \\
\hline 5 & 49.10 & 49.26 \\
\hline 6 & 83.10 & 83.25 \\
\hline 7 & 45.00 & 45.12 \\
\hline 8 & 91.90 & 92.11 \\
\hline 9 & 44.40 & 44.61 \\
\hline 10 & 40.80 & 40.99 \\
\hline 11 & 49.80 & 49.94 \\
\hline 12 & 36.20 & 36.66 \\
\hline 13 & 73.90 & 74.15 \\
\hline 14 & 78.80 & 78.86 \\
\hline 15 & 78.60 & 78.85 \\
\hline 16 & 89.90 & 90.16 \\
\hline 17 & 61.30 & 61.47 \\
\hline 18 & 80.10 & 80.30 \\
\hline 19 & 53.00 & 53.14 \\
\hline 20 & 49.10 & 49.02 \\
\hline 21 & 13.30 & 13.51 \\
\hline $1^{\prime}$ & 56.10 & 56.35 \\
\hline $6^{\prime}$ & 57.90 & 58.03 \\
\hline $16^{\prime}$ & 60.90 & 61.05 \\
\hline $18^{\prime}$ & 58.90 & 59.09 \\
\hline $\mathrm{COCH} 3$ & 172.30 & 172.45 \\
\hline $\mathrm{COCH}$ & 21.30 & 21.45 \\
\hline $\mathrm{ArCO}$ & 166.00 & 166.18 \\
\hline $1^{\prime \prime}$ & 129.70 & 129.86 \\
\hline $2^{\prime \prime}$ & 129.50 & 129.64 \\
\hline $3^{\prime \prime}$ & 128.50 & 128.66 \\
\hline $4^{\prime \prime}$ & 133.10 & 133.27 \\
\hline
\end{tabular}

investigated. The results demonstrated that, compared with the blank group, the contents of IL- 6 , IL- $1 \beta$, TNF- $\alpha$ and PGE-2 in the culture supernatant were significantly increased by treatment with LPS $(\mathrm{P}<0.05)$. Furthermore, compared with the LPS group, the contents of IL-6, IL-1 $\beta$, TNF- $\alpha$ and PGE-2 in the culture supernatant were significantly declined in the leflunomide + LPS and the drug intervention + LPS groups $(\mathrm{P}<0.01)$. Furthermore, the contents of IL-6, IL-1 $\beta$, TNF- $\alpha$ and PGE-2 in the culture supernatant in the intervention + LPS groups were higher than that in the leflunomide + LPS group $(\mathrm{P}<0.01$; Table VII). These results suggested that, the drug interventions may significantly improve the LPS-induced cellular inflammatory responses.

Effects of compound interventions on the expression of $H I F-1 \alpha$, VEGFA and TLR4. The effects of drug interventions on the mRNA and protein expression levels of HIF-1 $\alpha$, VEGFA and TLR4 were investigated by RT-qPCR and Western blot analysis,

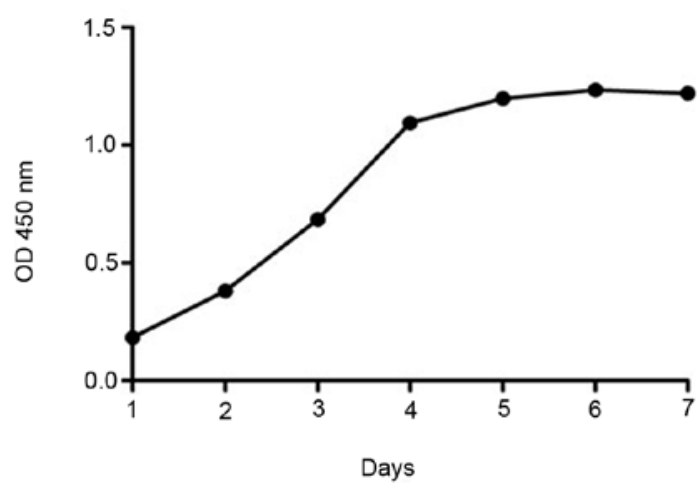

Figure 2. Growth curve of HFLS-RA cells. The proliferation of HFLS-RA cells was detected using a Cell Counting kit- 8 assay, at indicated time points. Experiments were repeated five times. OD, optical density.

respectively. The results from the RT-qPCR and Western blot analysis demonstrated that, compared with the blank group, the mRNA and protein expression levels of HIF-1 $\alpha$, VEGFA and TLR4 in the cells were significantly increased in the LPS group $(\mathrm{P}<0.05)$. Furthermore, compared with the LPS group, all the mRNA and protein expression levels of HIF-1 $\alpha$, VEGFA and TLR4 in the cells were significantly decreased in the leflunomide + LPS and intervention + LPS groups $(\mathrm{P}<0.01)$. Furthermore, compared with the leflunomide + LPS group, the mRNA expression levels of HIF-1 $\alpha$, VEGFA and TLR4 were higher in the intervention + LPS groups $(\mathrm{P}<0.01$; Fig. 4; Table VIII).

\section{Discussion}

In the present study, five monomeric compounds were isolated from the total alkaloids extracted from the roots of Aconitum soongoricum Stapf:: i) Aconitine, ii) songorine, iii) 12-epi-napelline, iv) 16,17 -dihydro-12 $\beta$, $16 \beta$-epoxynapelline, and v) deoxyaconitine. These components had certain pharmacological activities. The aconitine and deoxyaconitine were first isolated from Aconitum soongoricum Stapf., which were not only $\mathrm{C}_{19}$-type, but also diester-type diterpene alkaloids. These components represented the main analgesic and anti-inflammatory active ingredients in the herb, but they were also the main toxic components. In the present study, the songorine, 16, 17-dihydro-12 $\beta, 16 \beta$-epoxynapelline, 12-epi-napelline isolated from Aconitum soongoricum Stapf. were all napelline-type C20 diterpene alkaloids. These alkaloids had versatile pharmacological activities, including anti-arrhythmic effects, relaxing peripheral blood vessels and inhibiting tyrosinase activity. Furthermore, the toxicity of $\mathrm{C}_{20}$-type diterpene alkaloids was smaller than the $\mathrm{C}_{19}$ alkaloids. In particular, the toxicities of songorine and 12-epi-napelline were lower than that of aconitine, and the acute toxicity of songorine was much lower than that of aconitine, with higher physiological activity. Therefore, these components represented potential drugs for the treatment of the aforementioned diseases by regulating the neurotransmitter levels in the central nervous system. It is necessary to investigate the anti-arrhythmic and peripheral relaxing effects of these three $\mathrm{C}_{20}$ napelline-type diterpene alkaloids in Aconitum soongoricum Stapf. 


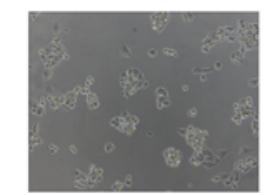

B

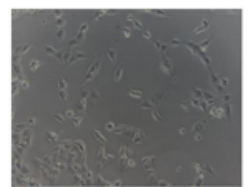

$24 \mathrm{~h}$

E

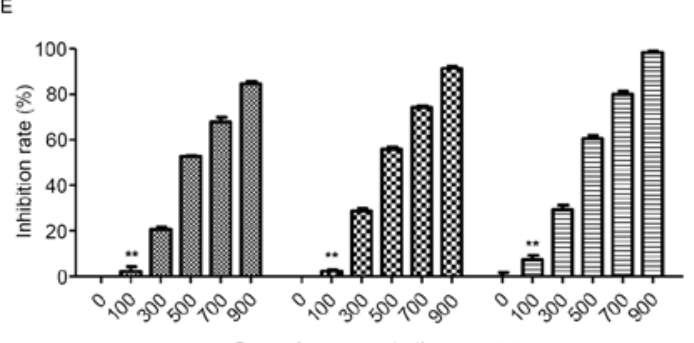

Songorine concentrations $(\mu \mathrm{g} / \mathrm{ml})$

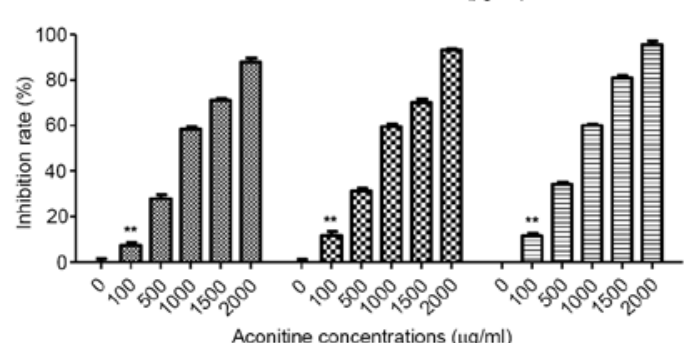

C

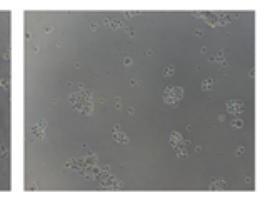

$72 \mathrm{~h}$

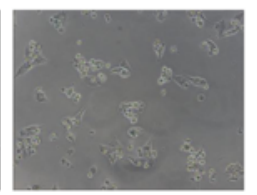

$72 \mathrm{~h}$

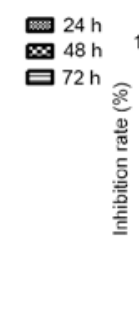

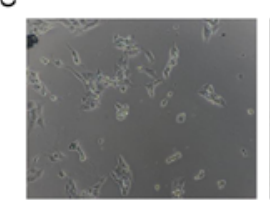

D

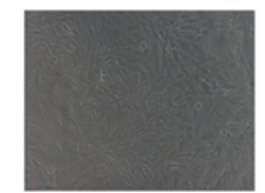

Control

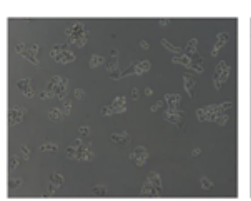

$48 \mathrm{~h}$

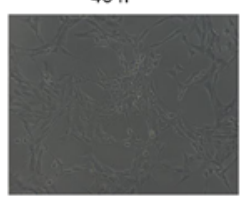

$150 \mu \mathrm{g} / \mathrm{ml}$

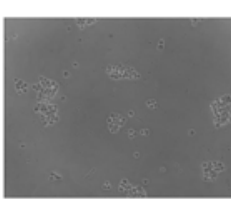

$72 \mathrm{~h}$
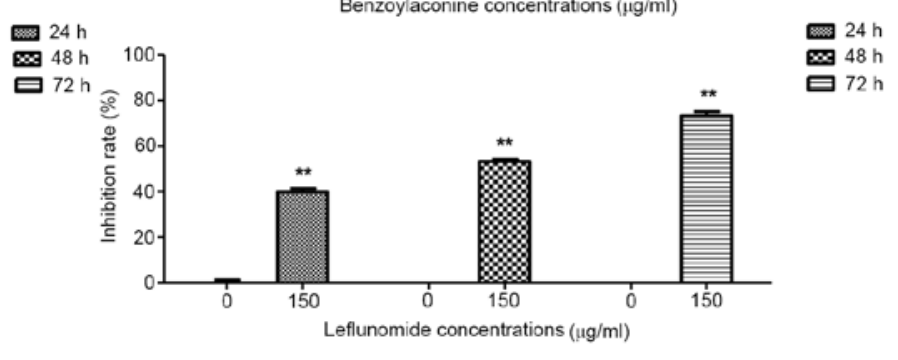

Figure 3. Effects of interventions on the proliferation of HFLS-RA cells. Effects of (A) songorine (900 $\mu \mathrm{g} / \mathrm{ml})$, (B) benzoylaconine (3,000 $\mu \mathrm{g} / \mathrm{ml}),(\mathrm{C})$ aconitine $(2,000 \mu \mathrm{g} / \mathrm{ml})$ and (D) leflunomide $(150 \mu \mathrm{g} / \mathrm{ml})$ on the proliferation of HFLS-RA cells were observed at indicated time points using an optical microscope (Eclipse TS100-F; Nikon). Scale bar, $100 \mu \mathrm{m}$. (E) Cell proliferation was also assessed using a Cell Counting kit-8 assay. The inhibition rate was calculated using the following formula: Inhibition rate $=\left(\mathrm{OD}_{\text {blank control }}-\mathrm{OD}_{\text {sample }}\right) /\left(\mathrm{OD}_{\text {blank control }}-\mathrm{OD}_{\text {reagent control }}\right) \times 100 \%$. Experiments were repeated five times. ${ }^{* *} \mathrm{P}<0.01$, compared with $0 \mu \mathrm{g} / \mathrm{ml}$. OD, optical density.

The results demonstrated that songorine, benzoylaconine and aconitine had anti-rheumatic activities in vitro. The inhibiting rate of leflunomide $(150 \mu \mathrm{g} / \mathrm{ml})$ on the cell proliferation within $24 \mathrm{~h}$ was $<50 \%$, and the optimal intervention time was set at $24 \mathrm{~h}$. The optimal intervention concentrations for other drugs were obtained from the data concerning the actual inhibiting rates from the CCK- 8 assay: $350 \mu \mathrm{g} / \mathrm{ml}$ for songorine, $1,000 \mu \mathrm{g} / \mathrm{ml}$ for benzoylaconine and $500 \mu \mathrm{g} / \mathrm{ml}$ for aconitine.

The results of the present study demonstrated that the treatment of LPS significantly increased the contents of PGE-2, IL-6, IL-1 $\beta$ and TNF- $\alpha$ in the culture supernatants and increased the intracellular mRNA and protein expression levels of TLR4, HIF- $1 \alpha$ and VEGF. These results suggested that LPS may stimulate the expression of inflammatory cytokines in HFLS-RA cells. Furthermore, LPS is the exogenous ligand for TLR4, which may promote the expression of TLR4, as well as the downstream HIF-1 $\alpha$ and VEGF. Furthermore, compared with the LPS group, the contents of PGE-2, IL-6, IL-1 $\beta$ and TNF- $\alpha$ culture supernatant were significantly decreased, and the mRNA and protein expression levels of TLR4, HIF-1 $\alpha$ and VEGF in the cells were significantly decreased, in the leflunomide + LPS group. These results suggested that leflunomide may significantly decrease the LPS-induced inflammatory responses. Furthermore, compared with the LPS group, the co-treatments of LPS together with songorine, benzoylaconine and aconitine had significantly decreased contents of PGE-2, IL- 6, IL- $1 \beta$ and TNF- $\alpha$ in the culture supernatant, as well as significantly downregulated mRNA and protein expression levels of TLR4, HIF-1 $\alpha$ and VEGF in the cells. These results suggested that these three components may also significantly improve the LPS-induced intracellular inflammatory responses. It is speculated that songorine, benzoylaconine and aconitine in Aconitum soongoricum Stapf. may inhibit the proliferation of HFLS-RA cells, which may involve the regulation of the TLR4, HIF-1 $\alpha$ and VEGFA pathways. Further studies are required to investigate the underlying mechanisms for the anti-rheumatic activity in Aconitum soongoricum Stapf.

The results from the ELISA demonstrated that, compared with the blank group, the contents of IL-6, IL- $1 \beta$, TNF- $\alpha$ and PGE-2 in the culture supernatant were significantly increased in the LPS group. Furthermore, compared with the LPS group, the contents of IL-6, IL-1 $\beta$, TNF- $\alpha$ and PGE-2 in the culture supernatant were significantly lower in the leflunomide + LPS and intervention + LPS groups. 
Table VII. Intervention effects on the cytokine content of the culture supernatant.

\begin{tabular}{lllcr}
\hline Group & IL-6 $(\mathrm{pg} / \mathrm{ml})$ & IL-1 $\beta(\mathrm{pg} / \mathrm{ml})$ & TNF- $\alpha(\mathrm{pg} / \mathrm{ml})$ & PGE-2 $(\mathrm{pg} / \mathrm{ml})$ \\
\hline Blank & $39.927 \pm 0.239$ & $10.062 \pm 0.503$ & $9.862 \pm 0.158$ & $8.846 \pm 0.096$ \\
LPS & $67.528 \pm 1.311^{\mathrm{a}}$ & $17.594 \pm 0.658^{\mathrm{a}}$ & $21.368 \pm 0.863^{\mathrm{a}}$ & $25.886 \pm 3.028^{\mathrm{a}}$ \\
Leflunomide + LPS & $42.204 \pm 0.906^{\mathrm{b}}$ & $11.540 \pm 0.566^{\mathrm{a}, \mathrm{b}}$ & $11.802 \pm 0.394^{\mathrm{a}, \mathrm{b}}$ & $9.226 \pm 1.146^{\mathrm{b}}$ \\
Songorine+LPS & $47.510 \pm 1.759^{\mathrm{a}-\mathrm{c}}$ & $12.910 \pm 0.482^{\mathrm{a}-\mathrm{c}}$ & $13.878 \pm 0.360^{\mathrm{a}-\mathrm{c}}$ & $10.966 \pm 0.846^{\mathrm{b}}$ \\
Benzoylaconine + LPS & $51.746 \pm 1.098^{\mathrm{a}-\mathrm{c}, \mathrm{d}}$ & $13.641 \pm 0.722^{\mathrm{a}-\mathrm{c}}$ & $13.836 \pm 0.566^{\mathrm{a}-\mathrm{c}}$ & $14.185 \pm 1.225^{\mathrm{a}-\mathrm{c}}$ \\
Aconitine + LPS & $45.590 \pm 1.392^{\mathrm{a}-\mathrm{c}, \mathrm{e}}$ & $11.816 \pm 0.489^{\mathrm{a}, \mathrm{b}, \mathrm{e}}$ & $12.341 \pm 0.596^{\mathrm{a}, \mathrm{b}, \mathrm{d}, \mathrm{e}}$ & $14.765 \pm 0.586^{\mathrm{a}-\mathrm{d}}$
\end{tabular}

One-way ANOVA followed by Tukey's test was performed for group comparisons. ${ }^{\mathrm{a}} \mathrm{P}<0.05$ vs. the blank group; ${ }^{\mathrm{b}} \mathrm{P}<0.01 \mathrm{vs}$. the LPS group; ${ }^{c} \mathrm{P}<0.01$ vs. the the leflunomide + LPS group; ${ }^{d} \mathrm{P}<0.05$ vs. the the songorine + LPS group; ${ }^{~} \mathrm{P}<0.05$ vs. the benzoylaconine + LPS group. LPS lipopolysaccharide.

Table VIII. Effect of interventions on HIF-1 $\alpha$, VEGFA, and TLR4 protein expression levels.

\begin{tabular}{lccr}
\hline Group & HIF-1 $\alpha$ & VEGFA & TLR4 \\
\hline Blank & $0.592 \pm 0.149$ & $0.745 \pm 0.157$ & $0.736 \pm 0.138$ \\
LPS & $1.287 \pm 0.304^{\mathrm{a}}$ & $1.409 \pm 0.139^{\mathrm{a}}$ & $1.426 \pm 0.296^{\mathrm{a}}$ \\
Leflunomide + LPS & $0.662 \pm 0.159^{\mathrm{b}}$ & $0.850 \pm 0.040^{\mathrm{b}}$ & $0.685 \pm 0.196^{\mathrm{b}}$ \\
Songorine + LPS & $0.903 \pm 0.190$ & $1.154 \pm 0.163^{\mathrm{a}}$ & $0.854 \pm 0.253$ \\
Benzoylaconine + LPS & $0.951 \pm 0.268$ & $1.141 \pm 0.215$ & $0.857 \pm 0.141$ \\
Aconitine + LPS & $0.852 \pm 0.208$ & $1.164 \pm 0.116^{\mathrm{a}}$ & $0.845 \pm 0.213$
\end{tabular}

One-way ANOVA followed by Tukey's test was performed for group comparisons. Compared with the blank group, ${ }^{\text {aP }}<0.05$ vs. the blank group; compared with the LPS group, ${ }^{\text {b }}<0.01$ vs. the LPS group. TLR, toll-like receptor; LPS, lipopolysaccharide.
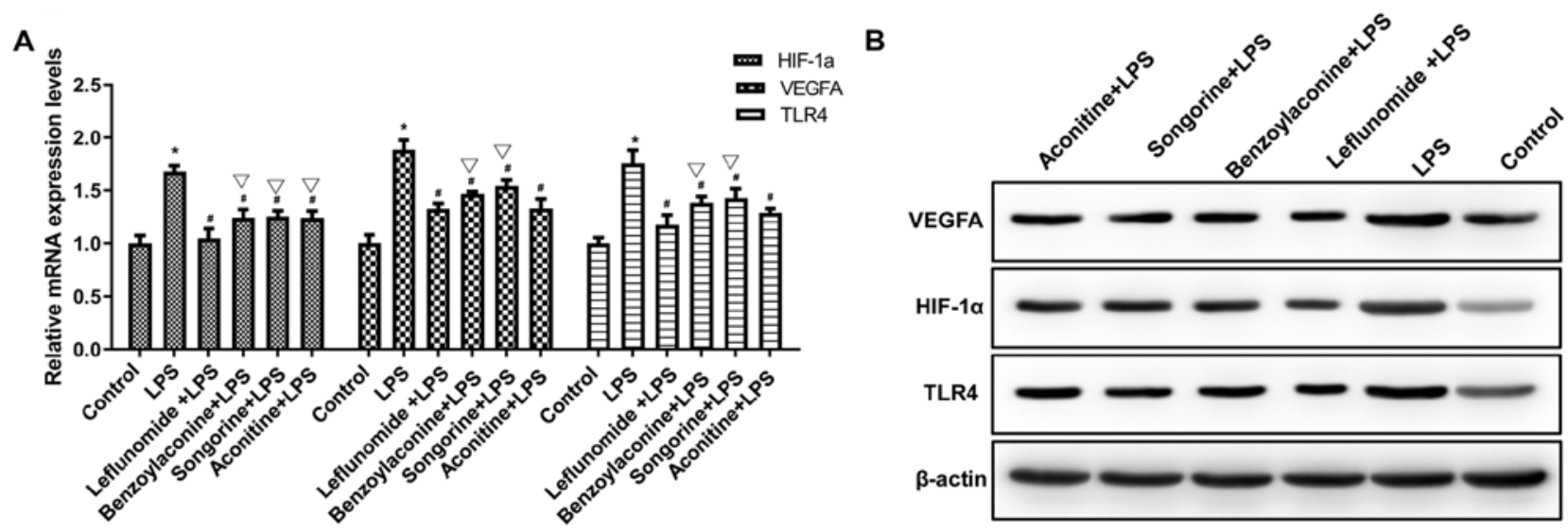

Figure 4. Effects of interventions on mRNA and protein expression levels of TLR4, HIF-1 $\alpha$ and VEGF. Cells were treated with LPS, in combination with songorine, benzoylaconine, aconitine and leflunomide. Next, the (A) mRNA and (B) protein expression levels of TLR4, HIF-1 $\alpha$ and VEGF were detected by Western blot analysis. Experiments were performed in triplicate. One-way analysis of variance, followed by Tukey's test, was performed for group comparison. ${ }^{*} \mathrm{P}<0.01$, compared with the control; ${ }^{*} \mathrm{P}<0.01$; compared with LPS; ${ }^{\nabla} \mathrm{P}<0.01$, compared with leflunomide + LPS. LPS, lipopolysaccharide.

The results from the RT-qPCR and Western blot analysis demonstrated that, compared with the blank group, the mRNA and protein expression levels of HIF-1 $\alpha$, VEGFA and TLR4 were significantly increased in the LPS group. Furthermore, compared with the LPS group, the mRNA and protein expression levels of HIF-1 $\alpha$, VEGFA and TLR4 were significantly decreased in the leflunomide + LPS and intervention + LPS groups. These results suggested that the monomer components of songorine, benzoylaconine and aconitine from Aconitum soongoricum Stapf. have certain anti-rheumatic activities, which may inhibit the proliferation of HFLS-RA cells. In these components, aconitine has the best inhibiting effect. We hypothesized that the anti-rheumatic mechanism may be through inhibiting the production of inflammatory cytokines and downregulating the expression levels of HIF-1 $\alpha$, VEGF and TLR4. 
In the present study, five alkaloids from the Aconitum soongoricum Stapf. were isolated, purified and identified. Some of the alkaloids have been demonstrated to have anti-rheumatic effects. However, the action mechanisms of the other alkaloids required further investigation. Therefore, in the present study, the isolated and purified songorine, benzoylaconine and aconitine were tested separately, to investigate the anti-rheumatic mechanisms and clarify the active constituents in the aconitum. In further in-depth studies in the future, the isolated chemicals would be used in combination, to provide evidence for the clinical treatment of related diseases.

For the antitumor mechanism of aconite, current studies are focused on their influence on the expression of multidrug resistance gene, mdr. It has been demonstrated that, with the treatment of aconitine alkaloids, the expression levels of ras proto-oncogenes would be inhibited, which in turn affects the Ras/Raf/MEK/MAPK signaling cascade and subsequently inhibits the tumor cell proliferation (26). However, due to the complexity of tumorigenesis and anticancer mechanisms, the underlying mechanisms of these compounds inhibiting tumor growth remain to be confirmed in the future. Furthermore, as for the toxic effects of these compounds on other cell lines, further studies are required.

The pharmacological effects and toxicity of the compounds were investigated and analyzed based on the literature review (27-29). Zhao et al (27) used the whole-cell patch clamp technique to study the effect of sogorine on the inward current of rat brain cells induced by GABA, and their results demonstrated that the compound may significantly inhibit the current, with an $\mathrm{IC}_{50}$ value of $19.6 \mathrm{mmol} / \mathrm{l}$. Furthermore, it has been demonstrated that songorine has an inhibitory effect on acetylcholinesterase, in a concentration-dependent manner (28). Furthermore, the half-lethal dose of songorine for the intravenous injection has been demonstrated to be $128 \mathrm{mg} / \mathrm{kg}$, which is $\sim 10,000$ times that of aconitine $(0.12 \mathrm{mg} / \mathrm{kg})$ and 5 times that of benzoyl aconitine (23 mg/kg) (29). Our previous study demonstrated that the Junggar aconite heating boiled processed products were superior to the other two types of processed products in terms of acute toxicity and pharmacological activity (11). The effective dose of the heating boiled processed products was $3.82 \mathrm{~g} /$ person/day, similar to the clinical dosage for the herbicides based on the Chinese Pharmacopoeia (30). Adverse reactions were as follows: The association between aconitine alkaloids and local anesthesia was investigated by quantitative structure-activity relationship (31). It has been believed that the local anesthetic effect results from the aryl ester group at the $\mathrm{C}-14$ position, and that the activity of the aryl ester group at the C-4 position are relatively weak. For the Junggar aconite, Aconitum Ranunculaceae, its main component is aconitine, a highly toxic diester aconitine. The toxicological effects of aconitine are mainly exerted by exciting and then paralyzing the sensory nerves and central nervous system, paralyzing the cholinergic nerves and respiratory center, leading to a series of $\mathrm{M}$ - and N-like symptoms of cholinergic nerves, particularly for the vagus nerve center of the medulla oblongata. Finally, the subject would die due to the respiratory paralysis and central inhibition. The main toxic effects of aconitine are based on the serious damages to the nervous and cardiovascular systems, inhibiting breathing and inducing arrhythmias.
In conclusion, the monomer components were isolated from Aconitum soongoricum Stapf., and the specific structure and physiological activities were investigated. The results of the present study may contribute toward improving the evaluation index of drug processing technology, standardizing the processing technology and quality control. However, further in-depth studies are required to analyze the toxicological activities of these monomer components of Aconitum soongoricum Stapf., as well as the hydrolysis mechanism and pathway during the drug processing.

\section{Acknowledgements}

Not applicable.

\section{Funding}

The present study was supported by the National Natural Science Foundation of China (grant no. 81460603) and 'Tianshan Xuesong' Autonomous Region Science and Technology Innovation Leaders (grant no. 2017XS12).

\section{Availability of data and materials}

The datasets used and/or analyzed during the current study are available from the corresponding author on reasonable request.

\section{Authors' contributions}

FZ conceived and designed the experiments; LZ and MS performed the experiments; JZ and MY analyzed the data; LZ wrote the manuscript. All authors read and approved the final manuscript.

\section{Ethics approval and consent to participate}

Not applicable.

\section{Patient consent for publication}

Not applicable.

\section{Competing interests}

The authors declare that they have no competing interests.

\section{References}

1. Hao DC, Ge GB, Xiao PG, Wang P and Yang L: Drug metabolism and pharmacokinetic diversity of ranunculaceae medicinal compounds. Curr Drug Metab 16: 294-321, 2015.

2. Hao DC, Xiao PG, Ma HY, Peng Y and $\mathrm{He} C N$ : Mining chemodiversity from biodiversity: Pharmacophylogeny of medicinal plants of Ranunculaceae. Chin J Nat Med 13: 507-520, 2015.

3. Wu M and Wei Y: Ethnobotany of Aconitum in Xinjiang. Chin Wild Plant Resources 23: 29-30, 2004 (In Chinese).

4. Mei H, Zhao F, Juan LI, Jun LU and Nie J: The study on acute toxicity of Xinjiang aconitum leucostomum worosch and its processed products. J Xinjiang Med Univ 7: 918-921, 2013 (In Chinese).

5. Malik J, Tauchen J, Landa P, Kutil Z, Marsik P, Kloucek P, Havlik J and Kokoska L: In vitro antiinflammatory and antioxidant potential of root extracts from Ranunculaceae species. S Afr J Bot 109: 128-137, 2017. 
6. Wu JJ, Zhu YF, Guo ZZ, Lou YM, He SG, Guan Y, Zhu LJ, Liu ZQ, Lu LL and Liu L: Aconitum alkaloids, the major components of Aconitum species, affect expression of multidrug resistance-associated protein 2 and breast cancer resistance protein by activating the Nrf2-mediated signalling pathway. Phytomedicine 44: 87-97, 2018.

7. Li J, Xu GQ and Zhao FC: Resources surveys of aconitum plants in Cinjiang province(II). Lishizhen Med Materia Med Res 12 2888-2889, 2011 (In Chinese).

8. Liu SM, Nie JH, Pan R and Zhao FC: Determination of the content of total alkaloid in Xinjiang genus Aconitum. J Xinjiang Med Univ 2: 193-196, 2012.

9. Khader SZA, Ahmed SSZ, Arunachalam T, Nayaka S, Balasubramanian SK, SyedAmeen ST and Ponnusamy P. Radical scavenging potential, antiinflammatory and antiarthritic activity of isolated isomer Methyl- $\gamma$-Orsellinate and roccellatol from Roccella montagnei Bel. Bulletin Faculty Pharmacy Cairo Uni 56: 39-45, 2018.

10. Lü S, Wang Q, Li G, Sun S, Guo Y and Kuang H: The treatment of rheumatoid arthritis using Chinese medicinal plants: From pharmacology to potential molecular mechanisms. J Ethnopharmacol 176: 177-206, 2015.

11. Jiang T, Xuan YH, Fu L, et al: Content changes of four alkaloids in the aconite of Junggar in the processing process. Chin Traditional Med 38: 2641-2646, 2016.

12. Siyi M, Lin YY, Zhang J and Zhao YC: Screening of anti-EGFR active ingredients in Aconite from Junggar, Xinjiang based on cell membrane chromatography. Chin Pharmacist 21: 766-771, 2018.

13. Wang F, Zhao J, Zhao F and Nie J: Study on the chemical constituents of diphtheria aconite. China Pharmacy 9: 1233-1235, 2015.

14. Zhong Y and Shu R: TLC identification of flavonoids and alkaloids from Chinese medicinal herbs. Chinese Folk Medicine 17: 9-11, 2017.

15. Liao SG, Li YT, Zhang LJ, Wang Z, Chen TX, Huang Y, Li J, Wang AM,Li YJ,Lan YY and Wang YL:UPLC-PDA-ESI-MS/MS analysis of compounds extracted by cardiac h9c2 cell from Polygonum orientale. Phytochem Anal 24: 25-35, 2013.

16. Djabrouhou N and Guermouche MH: Development of a stability-indicating HPLC method of etifoxine with characterization of degradation products by LC-MS/TOF, $1 \mathrm{H}$ and 13C NMR. J Pharm Biomed Anal 100: 11-20, 2014

17. Ma JD, Jing J, Wang JW, Yan T, Li QH, Mo YQ, Zheng DH, Gao JL, Nguyen KA and Dai L: A novel function of artesunate on inhibiting migration and invasion of fibroblast-like synoviocytes from rheumatoid arthritis patients. Arthritis Res Ther 21: 153, 2019.
18. Wen X, Chen X, Liang X,Zhao H,Li Y, Sun X and Lu J: The small molecule NSM00191 specifically represses the TNF- $\alpha / N F-\kappa B$ axis in foot and ankle rheumatoid arthritis. Int J Biol Sci 14: $1732-1744,2018$

19. Matsumoto Y, Ichihara H, Hino M, Umebayashi M and Ueoka R: Therapeutic effects of hybrid liposomes without drugs for rheumatoid arthritis. Drug Deliv 22: 619-626, 2015.

20. Zhou L, Li L, Wang Y, Gao Q and Geng YQ: Effects of RANKL on the proliferation and apoptosis of fibroblast-like synoviocytes in rheumatoid arthritis through regulating the NF- $\mathrm{BB}$ signaling pathway. Eur Rev Med Pharmacol Sci 23: 9215-9221, 2019.

21. Livak KJ and Schmittgen TD: Analysis of relative gene expression data using real-time quantitative PCR and the 2(-Delta Delta C(T)) method. Methods 25: 402-408, 2001

22. Li ZB, Lv GH and Chen DL: A study on the chemical constituents of alkaloids in radix aconiti agrestis. Nat Product Res 19: 9-14, 1997.

23. Xie H, Wei X and Wei B: Studies on the alkaloid constituents from Aconitum karakolicum Rap. J00A0Tropical Subtropical Botany 5: 57-59, 1997.

24. Zhang F, Peng SL, Liao X, Yu KB and Ding LS: Three new diterpene alkaloids from the roots of Aconitum nagarum var. lasiandrum. Planta Med 71: 1073-1076, 2005.

25. Fuente GDL, Reina M, Valencia E and Rodríguez-Ojeda A: The diterpenoid alkaloids from Aconitum napellus. Heterocycles 27: 1109-1113, 1988

26. Rao CL and Peng C: Study on the effect of aconitic alkaloid on RAS gene expression and its molecular mechanism of antitumor activity. Modern Preventive Med 37: 1098-1100, 1103, 2010.

27. Zhao XY, Wang Y, Li Y, Chen XQ, Yang HH, Yue JM and Hu GY: Songorine, a diterpenoid alkaloid of the genus Aconitum, is a novel $\operatorname{GABA}(\mathrm{A})$ receptor antagonist in rat brain. Neurosci Lett 337: 33-36, 2003.

28. Yang X, Wan L, He X and Song G: Inhibits acetylcholinesterase activity. Anh Agricultural Sci 36: 3499, 2008.

29. Li R, Feng F and Liu J: Research progress on structure-activity relationship of C20 diterpenoid alkaloids. Strait Pharmaceutical J 25: 1-4, 2013.

30. National Pharmacopoeia Commission. Pharmacopoeia of the People's Republic of China, Part One. Beijing: China Medical Science and Technology Press, 39, 2015.

31. Polishchuk P: Interpretation of quantitative structure-activity relationship models: Past, present, and future. J Chem Inf Model 57: 2618-2639, 2017. International (CC BY-NC-ND 4.0) License. 